\title{
Production System Analysis of Brem Processing Unit Case Study: The Industrial Centers of Brem in Kaliabu and Bancong Village, Madiun District
}

\author{
Ardaneswari Dyah Pitaloka Citraresmi ${ }^{1}$, Sri Kumalaningsih ${ }^{1.2}$, Imam Santoso ${ }^{1.2}$ \\ ${ }^{1}$ Postgraduate Program Department of Agroindustry Technology, Faculty of Agricultural Technology, Brawijaya University \\ ${ }^{2}$ Faculty of Agricultural Technology, Brawijaya University, Malang
}

\begin{abstract}
The purpose of this study was to determine the condition, the priorities, and the strategy development policy of the brem Madiun production system as an effort to increase the brem Madiun production system. The samples which are used were the brem industries at industrial centers of brem in Kaliabu and Bancong Village at Madiun District. The main instrument to collect the data was a questionnaire for 21 respondents of business leaders. Data analysis method which is used was Analytical Hierarchy Process (AHP). The results showed that the sequence of factors causing the decline of brem's production capacity were the final product $(0,477)$, capital $(0,244)$, raw materials $(0,123)$, human resources $(0,088)$, the tools and machinery $(0,041)$, and the method $(0,026)$. Benchmarks for goals to be achieved by the production system were the effectiveness of brem Madiun $(0,548)$, productivity $(0,227)$, efficiency $(0,138)$, and quality $(0,087)$. Strategies that can be done on developing the brem industry in Madiun are provision of venture capital to support the administrations, improvement of licensing services, improvement of joint venture accessibility on infrastructure production, supporting on marketing, improvement of human resources quality (coaching and training), development of product, improvement of business management, and development on network of business partnership respectively. After the several strategies development policy was formulated based on existing condition, then the performance of the brem Madiun production system can be improved.
\end{abstract}

Keywords : Brem, Production System Analysis, Strategy Formulation

\section{INTRODUCTION}

Brem is a traditional food that produced from white glutinous rice [1]. It have distinctive taste and high calorie. If it is consumed, this product is believed good for skin health, increase the body warmth, and add food appetite [2]. There are three forms of brem with two of them are in solid form, which are the Madiun brem and the Wonogiri brem. The third form is the wellknown Balinese brem, an alcoholic beverage produced in Bali.

Before solid brem was produced at Wonogiri, it was first introduced and produced in Madiun, which is why historically solid brem from Madiun is more well-known [3]. Brem Madiun production is concentrated at two villages, Kaliabu Village at Mejayan Sub-District and Bancong Village at Wonoasri Sub-District. The huge amount of brem production in Madiun makes brem becomes food icon of Madiun. In terms of organoleptic, brem Madiun has a yellowish white color with a combination of sweet and sour flavors. It is block-shaped with dimension of $0.5 \times 5$ to $7 \mathrm{~cm}$ with a hard but crumbly texture in the mouth. Brem Wonogiri's color is white with a sweet taste, thin and has a round shape with a diameter approximately 5 $\mathrm{cm}$, and it has a soluble texture [4].
Based on data from Department of Trade and Industry in 2004, there are totally 227 brem producers in Madiun, with a production capacity 9 tons/year in average [5]. Although it is a domestic production, brem can lift the economy sector due to the production amount of 96 business units reach 875 tons/year with a 9,8 billion rupiahs production value [6].

The opportunities of brem industrial's development have been growing big lately because government's policies encourage people to succeed the program of strengthening the local food [7]. The effort of promoting local foods is aimed to reduce dependence towards import products and to optimize the use of raw materials in order to make the access for small producers to productive resources becomes easier in order to increase productivity [8].

Seeing the potential and opportunity, brem industry has to be preserved even developed because it is potential to be the flagship commodity of Madiun. It is merely because until now brem production capacity continues to decline by $2.7 \%$ per year [9]. Based on data from Department of Trade and Industry in 2011, the production capacity of brem only reached 1 ton/year. If it continues, brem's 


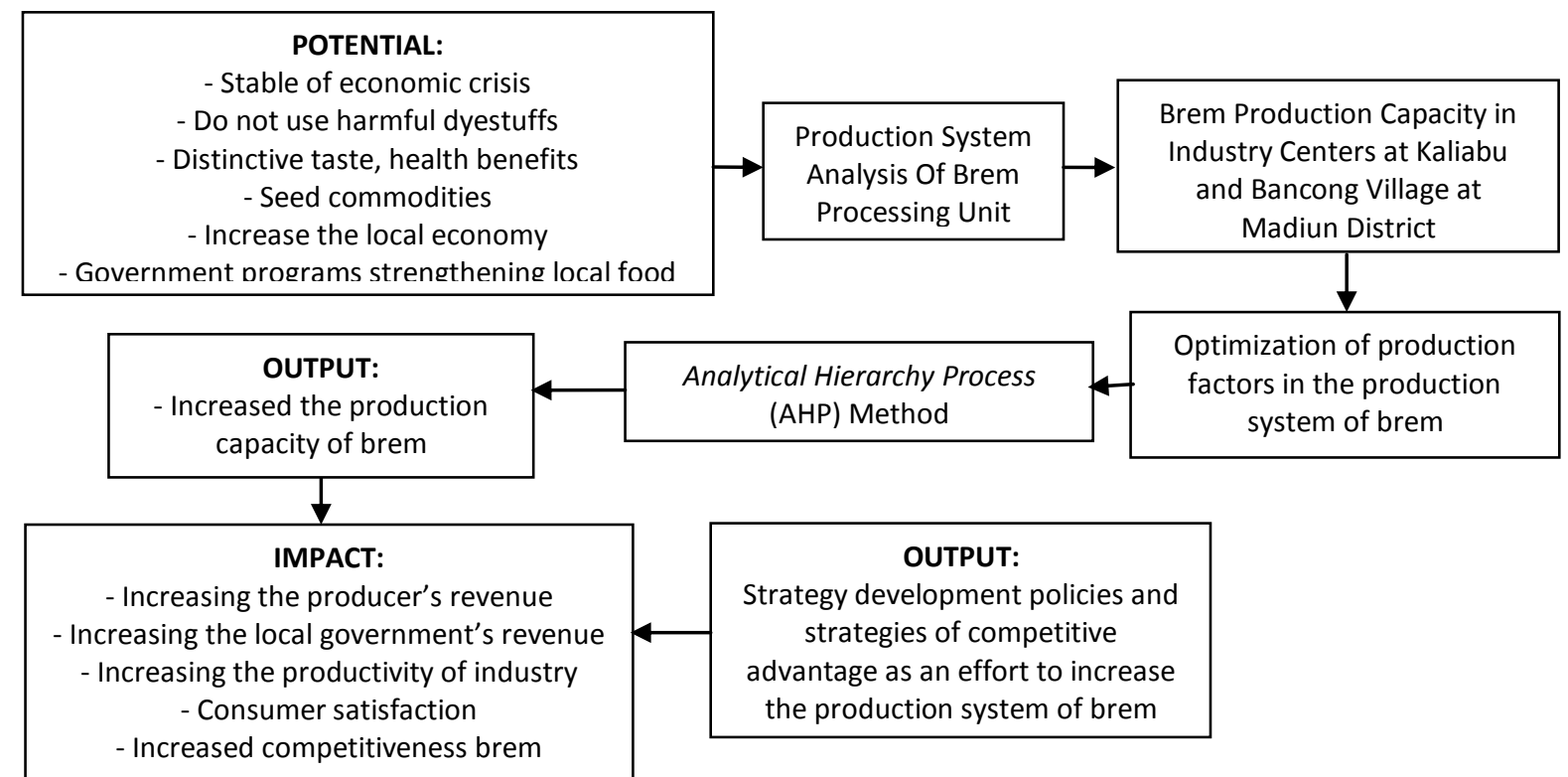

Fig 1. Research's Framework Concept of Brem's Production System

production capacity will keep declining and the production center might get shut down.

The problem that needs to be solved in this research is how to increase the production capacity of brem, so the industry won't shut down. One method that can be done to increase brem's production capacity is to do production system analysis to determine what factors should be optimized in the Madiun's brem industry. An ideal production system that should be adopted by the brem industry is the ability to use certain technologies in the process of transforming input into output [10].

To find out the major problems in the Madiun brem's production system, we need to do a thoroughly examination based on modeling system using descriptive analysis to find out the order of priority of production factors that affect the brem production systems and its development strategies.

\section{RESEARCH METHOD}

To obtain a model description of the condition from Madiun brem's production system, the research was carried out by system modeling so it can simplify complex problems and make it easier to analyze the influence of the production factors in brem production system, then create a strategy for its development. Weighting factors of each variables were used to determine the order of priority of the production factors that influence the brem production systems.
Data analysis methods which is used in order to make the value more comprehensive in weighting was Analytical Hierarchy Process (AHP) to assist decision makers in determining the strategy of development policy as an effort to increase Madiun brem's production system. The samples are used was brem industry at Kaliabu and Bancong Village. The main instrument to collect the data is a questionnaire for 21 respondents of business leaders. The framework concept of this research can be seen on Figure 1.

\section{RESULT AND DISCUSSION}

The results based on the weight of AHP assessment showed that the order of factors causing the declining of brem production capacity are the final product $(0.477)$, capital $(0,244)$, raw materials $(0,123)$, Human Resources $(0,088)$, tools and machinery $(0,041)$, and methods $(0,026)$.

\section{Final Product}

There were several factors that affect the final product in brem's production system, for example selling price $(0,42)$, the quantity $(0,218)$, quality $(0,207)$, and innovation $(0,154)$.

a. Selling price

Selling price became the highest priority because of selling brem, customer's satisfaction, and loyalty were measured from the sale price's suitability offered by the producers with the quality of the product. The average sale price set for each 100 gram brem was Rp 3.500,00 - Rp $5.000,00$ with $\mathrm{Rp} \mathrm{10.000,00} \mathrm{-} \mathrm{Rp} \mathrm{15.000,00} \mathrm{profit}$ per kilogram. Some producers sell brem in large 
quantities without a specific unit (one cardboard, sack, bundle, etc) so there has been no proper price list for each weight unit. In order to continue expanding its business, producers should begin to set the exact selling price per unit weight appropriately and clearly, so that the profits from the sale of the product can be calculated easily [11].

b. Quantity

The average brem production's capacity every month is $1000-1500 \mathrm{~kg}$, from the production process as much as 10-20 times per month, and it spent from 1000 to $2500 \mathrm{~kg}$ of glutinous rice. It's unknown for certain on how many brem's quantity being produced by Madiun brem's industry center every year, because the producers don't set a standard amount and there's no measurement on brem's weight because it is in the form of a package. To overcome the problems, brem's producers must set a standard amount that can be produced in a single production process. The quantity (number) of produced brem should be carefully calculated, based on market demand, so the consumers have no difficulty in obtaining the desired product [3].

c. Quality

Quality control is needed to produce a final product which has a good quality. To achieve the desired product quality, we need a standardized quality [2]. Currently, the quality produced from the brem industry is good enough. It can be proved that brem is always accepted by the big stores and distributors for resale. Usually the big stores or distributors have set certain quality standards, based on consumer preference. In addition, damaged brem caused by the failure of the manufacturing process are few, and there is only few complains regarding to it. As long as the taste is good, brem's shape and packaging is not a major problem, but it would be better if the shape and packaging quality are taken into consideration in order to increase the whole brem's quality for customers [13].

d. Innovation

Innovation that has been done is to add new flavors only, not changing brem's shape. All this time, brem takes form in rectangular shape, consists of 3 types of size which are $10.5 \times 18.5$ $\mathrm{cm}$ with a weight of $400 \mathrm{~g}, 7 \times 19.5 \mathrm{~cm}$ with a weight of $230 \mathrm{~g}$, and $9.5 \times 14 \mathrm{~cm}$ with a weight of 200 gr. For the flavors, since 2006, producers have introduced new flavors, such as chocolate and strawberry. It is expected that the variety of flavors can provide an alternative option to the consumers who do not like the taste of the original brem which is slightly sour with a strong taste of alcohol.

The changing of taste of the product will increase the price up to Rp. 1.000,00 from the original price. It is time to apply the innovation in the industry to support the potential brem to enter the global market. With an intense competition in the field of quality and service and a rapid market change, the development of products such as flavors, models, and packaging can be used to maintain the selling value of the product [14].

\section{Capital}

There are several factors that affect the capital in the brem's production system, for example a source of capital $(0,566)$, external support $(0,194)$, financial management $(0,130)$, and the quantity of capital $(0,11)$.

\section{a. Capital Source}

The sources of capital for Madiun brem industry is partly derived from other parties. This is because the level of per capita economy is low, so it's impossible to cover all of expenses with the business owner's personal finance. Other parties which mentioned are banks and distributor of raw materials. Capital support which is provided by distributor of raw materials is lending the glutinous rice to the producers of brem with using product's rotation system. The brem's producers will take first the raw material from the seller (with or without down payment). After they sell, they will pay for the purchase of glutinous rice in the previous period. For cooperation with institutions, only some producers are eager to borrow capital to the bank because most of them do not know how to borrow it from the bank. It's either because the interest loan is too high or the requirement is too difficult. Based on the capital problems, the solutions that can be implemented is the provision of capital support from both government and private, cash or soft loans with low interest. The role of government in providing credit facilities for brem industry will have a positive impact in increasing production capacity, and producers and regional's revenue [15].

\section{b. External Support}

To support its development, it takes a huge investment, because it is a domestic industry with a small production capability. Department of Cooperative and SMEs needs to work with relevant parties to provide external provision in the form of capital assistance, either through banking and non-banking institutions 
[16]. Department of Cooperative and SMEs has provided revolving fund to support the SMEs who are registered as its members. The quota of revolving fund for SMEs from the district budget in 2011 was 600 million rupiah, which will be distributed to 58 SMEs including brem industry. But there is no significant impact to the industry because the support which provided is technical and it is given only once without any specific guidance about the usage of the fund, so there is no good progress appear.

c. Financial Management

The conditions that occur in the Madiun brem industry is there are some producers which control their flow of business finance, but some don't. The financial arrangements is done in different ways. There are financial reporting, separating the use of the money for personal and business interests, and using the profits for capital turnover. But there are also producers who do not know the importance of financial management in the industry. They do not separate the use of the money to be used for capital turn over and business development, and it leads to run out to meet personal needs. This is what causes the difficulty of developing into a major industry. Therefore, producers must learn to manage their business finances.

Some basic financial management for SMEs to be considered by producers, such as [17]: (1) Separating personal finances with business, (2) Calculating the initial funding requirements to ensure that the capital is sufficient to run the business in the future, even estimating how long the capital can be obtained again, (3) Planning for the use of money, (4) Having a well - managed financial accounting, (5) Calculating the profit correctly, (6) Playing a faster cash flow, (7) Preparing an emergency fund to anticipate a sudden needs so that the finance won't be in chaos, and (8) Saving some profits for product innovation.

d. Quantity

Determination of the capital quantity of brem industry is not calculated everytime by the producers. It is only done at the beginning, then the profit gained by the sale will be used to buy production needs, without counting the exact needs. It occurs frequently until the producers can not precisely define working capital for their business needs. The amount of capital owned by Madiun brem's producers varies between 1-45 million rupiahs in average. The capital which is mentioned is the capital for purchasing of glutinous rice. Glutinous rice price is $\mathrm{Rp} 8.500,00$
/ $\mathrm{kg}$ in average, and the amount of raw materials usage is different in each industries, ranging from 2.5 to 50 quintals per month. In order to evolve brem industry, producers must increase the amount of capital which is used, so it can be used to buy glutinous rice in bigger numbers. The employee can be also increased, and the producers can buy more advanced tools and machines, and the capital can also be allocated for product promotion so that brem industry's development can show its progress [18].

\section{Raw Materials}

There are several factors that affect the raw material in brem's production system, for example procurement management $(0,470)$, pricing $(0,151)$, time of procurement $(0,116)$, suppliers $(0,110)$, quality $(0,105)$, and quantity $(0,048)$.

a. Procurement Management

Glutinous rice is a seasonal product, susceptible to pests, and has a large volume. Glutinous rice also has varied quality, in which to increase sales, sometimes a good glutinous rice is mixed with the one which has a lower quality. All risks concerning the procurement of glutinous rice must be set properly, so its availability can support the sustainability of brem's production. Risks can be minimized by meeting the specifications of raw materials required for the manufacture of brem, through the development of standard specifications required for glutinous rice industry, where producers specify capacity to meet the standards of production and inventory, as well as standard delivery [19]. The aspects of material handling needs improvements where previously the glutinous rice's procurement and storage management is not well-controlled, which is placed inside a sack on the floor, ground, and kitchen. Humid temperature may degrade glutinous rice's quality. There's also pests infestation such as fleas and rats. Fixing the storage aspect in each storage room is a beginning step, so the the risk of material damage can be minimized since the beginning and it can produce high-quality brem [3].

b. Pricing

Glutinous rice price ranges from $\mathrm{Rp}$ $8.000,00$ to $\mathrm{Rp} 8.500,00$. The materials needed by the company may affect the level of quality and quantity and selling price. If the price is too high and the material obtained by the quality and quantity is also dissatisfying, it will affect the level of production costs and selling prices of products, so companies will suffer losses. Producers must be clever in balancing fluctuations in raw material prices and costs of 
production, so that the gap between the price of raw materials and production costs can still be covered by the profits earned from the sales of brem [7].

c. Time of Procurement

The average procurement time of raw material performed by the producers at less than 10 times / month (approximately once a week, the quantity is 5 quintals for every procurement). The procurement of glutinous rice is done by the producers who order it from the supplier, then the supplier sends the ordered glutinous rice, based on approved schedule. During this research, it is known that the supply of glutinous rice is always available all the time, so the time procurement of raw materials is not a particular problem for brem's producers. Obstacles that may be encountered in the procurement of glutinous rice is if the producers does not regularly schedule the glutinous rice's procurement, it can cause a shortage of raw material likes when glutinous rice is difficult to get or the price is very expensive so brem's production might be paused temporarily.

\section{d. Supplier}

All this time the company has done purchasing activity and supplier selection well, where production process never stops because of raw materials shortage. Brem producers do the glutinous rice sale and purchase transaction with distributor mostly from outside of Kaliabu and Bancong Village (Caruban, Takeran, even Madiun which specially imports glutinous rice from Vietnam) and also distributor from Kaliabu and Bancong Village (local farmer as well as market). Choosing suitable supplier for the company is one of important factors that can bring profit. The main factor which are to be considered by company when choosing a supplier are [20] : (1) Price, (2) Quality, (3) Service, (4) Location, (5) Supplier stock's policy for helping in sudden need of raw materials case, and (6) Flexibility.

e. Quality

To guarantee the final product have good quality, brem producer must ensure that glutinous rice which is obtained from supplier must have good quality and it is not mixed glutinous rice (mixed with bad quality one) that will cause number of brem sales dropped. All this time the quality of raw materials for continuation brem production is guaranteed because it is provided in good condition by the supplier so that brem which is produced is also good. So far, the decrease of brem quality is caused by humid room temperature, pest infestation, rat, insect, etc. Therefore, in order to keep glutinous rice's quality until production process, producer must pay attention to storage method, that is storing in sealed containers, not humid, and pest free [1].

f. Quantity

So far, the number of glutinous rice is always adequate for the production capacity and brem is always available all the time. Therefore, the quantity of raw materials is not really a problem to fulfill brem's demand in the market. The amount and availability of raw materials have high risk value because if the number of glutinous rice is limited, then the number of brem produced will drop, resulting in the number of brem product that can be marketed also drop and causing in decreasing of producer's income [21].

\section{Human Resources}

There are several factors which influence the human resources in brem production system, for example competency $(0,407)$, management $(0,351)$, productivity $(0,093)$, development activity $(0,092)$, and quantity $(0,056)$.

\section{a. Competency}

In running a brem-making business, it is known that educational background of labor is mainly graduated from elementary school, followed by junior high school and senior high school. The impact from labor's low educational level is lack of creativity and innovation in making new product that suits the rapidly changing market demand, causing brem can not globally compete yet [16]. Therefore, for the next labor recruitment, it's better to pay attention to labor educational level so it won't be too low and easier to develop their potential. Besides educational level, it's known that labor skill is not because result of training, but because they grow accustomed to the same job over and over again. Brem making is already done since 1985 with same process, so indirectly worker skill come from the routinity. To increase the labor competency, the thing that can be done is to give training for skill and new product innovation to labor so it can be applied in brem industry [16].

b. Human Resources Management

In Madiun brem industry, human resources management is activity performed by employing local people or family so they won't be unemployed. In one industry usually have five members on average. The job is split informally. The business leader only gives order verbally without any written order letter about the work's details. The salary given for the labors is 
calculated per day, on average $\mathrm{Rp} 25.000,00$. Mentioned the salary is based on minimum regional salary which is applied in Madiun District in 2009 - 2011 in the amount of $R p$ 720.000,00 [22], so that salary received by labor in a month (with average 20 working days) is Rp 500.000,00. It is not differ much compared with the minimum regional salary.

c. Productivity

In brem industry, the work begins at 07.00 until 15.00, including preparation of material and tool, production process, molding, drying, break, etc. Working time for each labor is 8 hours, with five workers, and brem that can be produced a day is $50-100 \mathrm{~kg}$ brem, it means one labor productivity is $10-20 \mathrm{~kg} /$ day in average. Labor productivity is a comparison of result achieved from labor role (output) with the whole resources (input) that is used per unit time [15]. In brem industry, men labor is more needed because this industry relies on physical strength. Sex factor is also determining the participation and productivity level in work. In general, man will be more productive to the work that rely on physical strength [23]. Age of labor in Madiun brem industry is almost even, ranging from 31 60 years old because that age is the most productive age to work. In demographic analysis, residents age structure divided into 3 groups; (a) the young age group, under 15 years old; (b) the productive age group, 15 - 64 years old; and (c) the old age group, over 65 years old [24].

d. Development Activity

During the research (in the last 5 years) the business leader and the labors admitted that they never got the job training in brem making business. This is caused by lack of approach intensity from related parties to support the development of industrial centers and from the society itself. There's lack of information about it so the access to get the job training is hampered. Whereas development activity is needed to improve the labor's performance. To improve the performance, activity that can be done is giving a training. With training, they are prepared to have skill to be ready, to know, to understand, and to develop a systematic thinking method and they can solve problems in work, and get the suitable salary with what they do [25].

e. Quantity

There are 21 industries that employ 1-5 labors. Number of labors are adjusted with the amount of process and company's production capacity. Five labors are considered able to handle the whole production process until they can produce brem as ordered. Moreover, the number of labor are adjusted with the salary given by the company, based on the income received. Brem business is a micro enterprises, where the amount of labors employed is a standard amount for micro enterprises. SME is divided into 3 categories : (1) micro enterprises with workers less than 10 people, (2) small business with 10-99 workers, and (3) medium business with $100-499$ workers [25].

\section{Tool and Machine}

There are several factors which influence tool and machine in brem production system, for example amount $(0,571)$, volume $(0,3)$, and sophistication level $(0,129)$.

a. The Amount

Determining amount of tool which is used in brem industry isn't performed by mathematic calculation which follows formula of efficiency and effectiveness. Determining the amount is only performed in the beginning of production, where firstly the tool which is used is only one, and then additional tool will be adjusted with additional production capacity. If the decision is done appropriately, producer can calculate brem production which is capacity that can be produced in a certain period of time [26]. The number of tool and machine used in brem industry for each process step is only one, so the output in each station is limited. However this amount is already meets the production capacity. Some tools are still occasionally overloaded, for example crock that is used for cooking glutinous rice and cormorant that is used for stirring the extract of fermented glutinous. This is the reason why producers must pay attention to capacity need, for example, adding the tool or to replace them with the bigger capacity so there will be no overloading and it will not get overwhelmed if there is increasing demand.

b. Volume

Machine and tools capacity used in brem industry is relatively small so production process is limited. The amount of glutinous rice that can be steamed is less than $100 \mathrm{~kg}$ per day. The activity of determining volume / tool and machine capacity in brem industry isn't performed in detail, and tools which are used have the same capacity from year to year. The tool capacity is not adjusted with total production capacity, but the opposite way. It means the amount that each tools can produce in every step is considered as benchmark in determining total production capacity of brem. In brem industry, tool capacity planning isn't 
decided by producer from the start, so when there's an increasing demand, the consequences are they have to add the amount of tool. This is happens because the tool which is used has capacity/volume that cannot be changed. However if the brem's demand become stable again or even have a tendency to decrease, the tools which are already bought can not be used and it will become a futile capital investment. Determining tools volume / capacity needs to be done since the beginning carefully. It needs to be adjusted with average calculation of brem demand for a certain period, so when there is a change in capacity for the time being, producer doesn't need to spend more expenses [27].

c. Sophistication Level

In brem industry, sophistication level of tool and machine technology isn't really matter for brem production process. This is because the tools which are used mostly are a traditional one; cormorant for cooking the glutinous rice, crock for boiling the extract of fermented glutinous, plastic basin for soaking glutinous rice, wood press for squeezing or extracting the fermented glutinous, long wooden chair for cooling, flattening, and molding brem, plastic as a cover for brem dough when molded, a ruler for measuring brem piece desired, and also a knife for cutting the brem. Moreover there are also modern tool used such as a fan to cooling the cooked glutinous rice, a mixer to stir extract of fermented glutinous and additional ingredients, and diesel engine as a source of mixer propulsion. If producer want to improve the quality and quantity of brem, the industry must consider the using high technology tool. For example, the furnace stove can be replaced with gas stove, wooden plate stirrer can be replaced with electric mixer, wooden plate printers can be replaced with printing machine, wooden press can be replaced with hydraulic press machine that is specially used for taking extract of materials, etc. The more sophisticated technology is used, the less error it would be. Even more if technology used is based on computer when performance from machine is well-programmed, so the labor will only operate the machine and controll the output from that machine [20].

\section{Method}

There are several factors that effected method in brem production system, for example standard operating procedure $(0,298)$, time efficiency $(0,282)$, process type $(0,274)$, and quality control $(0,147)$.

\section{a. Standard Operating Procedurs (SOP)}

Approximately 21 industries have regular production system, which is to produce brem everyday. To produce 1000 - $1500 \mathrm{~kg}$ brem every month, production process conducted less than 10 times per month and consumes glutinous rice less than $1000 \mathrm{~kg}$. SOP application in brem industry isn't optimally performed because producer and labor's lack of understanding about the importance of SOP application to get a product with an optimal quality and quantity. If an industry doesn't have SOP, it can be easily predicted that it will not grow 5-10 years after. This is because all the activity inside doesn't have standard reference [28].

b. Time Efficiency

In brem industry, time efficiency is often ignored. Many labors become idle because of discontinous type of process. To perform the next step, sometimes the workers have to wait until the previous process finished. This is happened because they don't make an alternative work that can be done on the day if the main work is already finished or needs time to be finished, so there's a waste of time. Besides, another condition related to inefficiency of time are the using of traditional tool and doesn't apply SOP in brem's production system. The product isn't accepted by market, so it has to be thrown away or not marketed, making the producer reproduce brem to fulfill the demand. Working efficiency is a basic principles to do an activity which aims to get the desired result with minimum work, related with time, work method, and cost. Efficiency can minimize the loss or wasted resources in performing or producing something [18]. Solution that can be applied is each worker must schedule the implementation of all activities until they finish, with condition that the time is to be used as short as possible, on time, and with minimum cost. Productivity is often associated with efficient system method, so the production process occurs on time and there's no need to do overtime with all of the implication, especially cost implication [29].

\section{c. Process Type}

Production flow type that is used in brem industry is batch type. Production process can't be performed continuously because there is a step when fermented glutinous rice is processed into a fermented glutinous, until it becomes brem. So there will be only 4 times fermentation process and 4 times brem making process in a month. Process type is not really a matter activity in brem production process because producer 
perform the same production process everyday, and the success of the production process until it becomes brem depends on the success of steps beforehand.

\section{d. Quality Control}

Quality control in brem industry isn't optimally performed. This is proved because there are still a defective product / reject, whether in production process nor after it becomes the final product (brem). Brem producers don't have a quality standard written for product and production process. It causes no similarity of performing process and also the final product, whereas if the control of brem's production process is performed well, the company can minimize the overall cost of production process [28]. Solutions that can be applied to guarantee that the product is in the good condition [10].

- Assign quality standard in size, expiry, color, shape, price, etc using standard tool.

- Find an inspector or controller who has the needed skill about tool usage and maintenance.

After identification is conducted toward factor and indicator, the next step is identification to target that brem Madiun production system will achieve.

\section{WORK EFICIENCY}

The best solutions for brem industry to maximize work time efficiency to produce big amount of product with minimized production cost, is to maximize supervision for every process, and to implement disciplined SOP. The work eficiency is measured qualitatively ; therefore the main factor which affects work efficiency is human [30]. Human can create efficient working process using his mind, thought, and knowlodge. It is obtained from the observation that, in order to increase work efficiency, these following efficiency elements have to be increased [23]:

a. Awareness

Workers will know the importance of working efficiently based on the standard by increasing their awareness. It can result that every worker can maximize his potential for the best output.

b. Skill

Every work has done by an expert will result better and faster than one which is done by someone who is not expert on it. We can increase workers skill by giving training to support the job. Besides, skill improvement can be done by providing supporting device so that the work can be done easier and faster.

\section{c. Discipline}

Awareness and skill won't guarantee that the work will be efficient if it is not done with discipline. Thus, efficiency needs a standard which will become director of desired result, so that all of resources can be in one vivid direction, and it is not out of the track.

\section{PRODUCTIVITY}

Brem productivity is considered weak, proven by improper use of workers and brem material. If the average workers are five people with eight working hours / day and five days a week, and average amount of material is 1000 $2500 \mathrm{~kg}$, then the result of brem's production should be more than the result now, which is only $1000 \mathrm{~kg} /$ month with Rp 10.000,00 - Rp 15.000,00 / kg income. Besides, the impact of productivity is good in brem industry. If productivity can be done well, then every worker can produce more output, so they can produce more brem which can be sold and they will get more income [16].

Generally, to increase productivity we need to increase output and/or lower input. There are five ways to increase the productivity of brem industry, which are [31]: 1) Implement cost reduction program, by producing output with the same quantity, but using smaller amount of input, 2) Manage the growth, which is increasing the output with bigger quantity by increasing input usage in smaller quantity, 3) Working agiler, which is using the same input to increase output, so that production cost for every output unit will be smaller, 4) Reducing activity, which is reducing production activity and also removing unproductive asset, and 5) Working more effectively, which is increasing the output but reducing the input by working more effective so that we will get more output by using less input.

\section{EFFECTIVITY}

Brem industry effectivity is considered weak, which can be seen from the use of natural resources which is not optimum in production system. All these years, the production process which is done and maintained for years in fact is not enough to cover the demand of brem product in market.

Brem production ineffectivity can be seen from the decreasing of brem production and low product innovation rate, so it decreases brem demand every year. This shows that brem is not effective enough to meet the consumer's need of healthy snack in the market. Besides, the effect from effectivity is very good for brem industry. If it is done well, brem has potential to dominate healthy traditional snack market. Production 
process has to be done correctly to increase brem industry effectivity, with the proper amount of material, workers, and process time, so it can produce the best quality and quantity of brem. Therefore, brem will be saleable in the market with high price and the profit will increase [32].

\section{QUALITY}

During production process, the quality of the process is also considered bad because it produces too many reject product, especially from drying station. If the process is done in rain season, then the brem will not dry optimally because the amount of sunlight is less than it is needed, so that the brem will be mushy, and the smell will be musty easily, the color will be less demanded, and the taste will be no good. Besides drying station, there will be some steps which are considered bad, for example fermentation step where the failure of fermentation process caused by the unsupporting environment will result the half-baked ouput will be disposed away and the producers has to repeat fermentation process from the beginning. It needs seven days to do it. In addition, the mixing step of fermented glutinous extract is done in small crock so that much dough will spill and the amount of mixed fermented glutinous extract is small, and also the stove which is used is still traditional. The heat adjustment of it is not spread equally; it causes glutinous and burnt side effect.

\section{Brem Production System Development Strategy}

It needs a good strategy to develop the industry so the producers can develop the potential and resources which they own. The strategies that can be done to develop Madiun brem industry are follows:

a. Venture Capital Support Administration

In order to develop brem industry in Madiun, the government of Madiun District gives venture capital support to brem producers through banks with low interest; it is soft loans program with maximally for 20 million rupiahs for two years installment with $6 \%$ per year interest. Capital factor, especially money has big role in a business, because money is needed to pay employees salary, buy material, equipment, etc. In small scale industry, money seems to be a constraint to develop the business. This propels the government and private corporation to provide facilities, in the form of venture capital support or soft loans credit [15].

b. Improvements in License Service

There are many small scale industry which don't have business license. They only produce brem, and they send it to bigger companies which have business license, in order to get the capital faster. For them, the cost to make or renew business license is quite expensive and the process itself is complicated. That is why it becomes constraints for those typical business who don't have adequate information and knowledge. It is also because they come from middle to lower economic status resulting difficulty to get business license. one them is SIUP. SIUP is business license issued by government agency through Trading and Industrial Service in city or area level based on company's domicile. SIUP is used to run the business of trading / service in Indonesia based on KLUI (Klasifikasi Lapangan Usaha Indonesia/Indonesian Busines Field Classification) [33].

c. Improvements of Joint Venture Accessibility of Production Infrastructure

Department of Trade and Industry of Madiun District cooperate with other parties to provide infrastructure support, such as :

- Efficient technology support such as press hydrolic, printing machine and cutting machine from central agency of assessment and application of technology.

- Cooperation with Research and Standardization Association in Surabaya about the utilization of used water from glutinous rice into fresh drink.

d. Marketing

The government also gives support related to brand name besides marketing support. They give support to get business brand right in order to enable the brem business can have their own patended brand. This is done to avoid other people to imitate their brand. While the support to get business license letter is attempted, therefore, the business can have legal capacity for their business. It gives opportunity to enlarge the business in order to get facilities such as credit assistance and coaching program, briefing, and supervision to create wholesome, orderly, and honest condition [34].

e. Human Resources Quality Improvements (Coaching and Training)

Not all of businessmen and workers are aware of the importance of good and proportional business management. Therefore Disperindag of Madiun District occasionally direct brem producers to be involved in business management training in some places in order to improve the human resources quality. 


\section{f. Product Development}

Competition in quality and service happens very intensively and the market changes rapidly. That is why product development can be used as a tool to protect the products selling ability. Produk development creativity and uniqueness and new benefit will attract the consumer's interset, including innovative patterns and fresh colors [13]. One of the way which can be applied for the product development is the shape transformation from brem bars into jelly salut chocolate that will enable the consumer easier to consume the brem, because the shape is small, compact when eaten and brought everywhere.

g. Business Management Improvement Industrial management used by brem producers is still simple and traditional, based on its character and scale which is relatively small. Almost all of brem industries are managed by an individual, whithout interference from the government. The organization is not complicated, so there is some jobs which is done by one person, such as marketing and administration and finance. Besides, the finance is not separated from household, because the management is done by family, so that the result will be used directly for daily needs.

Department of Trade and Industry of Madiun District focuses the coaching in terms of business management, by giving facility and counseling directly by inviting speaker from university in Madiun. The indirect coaching can be done when the brem producers borrow money. They are given counseling that they pay the installment that is why they have to be able to manage it well.

h. Building Business Partnership Network

To increase product marketing quality and quantity, then brem industry has to have breakthrough and partnership and network with some related associations. Partnership network with global certified food companies, for example Garudafood, Indofood, Wingsfood, etc, can be used to learn how those companies market their products which are suitable with the right market target. There are some things which can be learned, for example what product to produce, the combination prosess, and shape and packaging innovation. Besides, the partnership which can be done is partnership in making a new product with brem as the basic material, where the brem producers will supply brem continually to the companies to be processed into chocolate candy, ice cream, etc. Besides big companies, partnership network can be also done with some experts from university, to diversify brem, for example into a jelly candy and jenang so that they can create new product innovation with brem as the basic material.

\section{CONCLUSION}

1. The Conditions of Brem's Production System

The sequence of factors - factors causing the decline in brem's production capacity are the final product $(0,477)$, capital $(0,244)$, raw materials $(0,123)$, human resources $(0,088)$, the tools and machinery $(0,041)$, and the method $(0,026)$.

There were several factors that affect the final product in brem's production system, for example selling price $(0,42)$, the quantity $(0,218)$, quality $(0,207)$, and innovation $(0,154)$. Factors that affect the capital in the brem's production system, in example : a source of capital $(0,566)$, external support $(0,194)$, financial management $(0,130)$, and the quantity of capital $(0,11)$. Factors that affect the raw material in brem's production system, in example : procurement management $(0,470)$, pricing $(0,151)$, time of procurement $(0,116)$, suppliers $(0,110)$, quality $(0,105)$, and quantity $(0,048)$. Factors which influence the human resources in brem production system, in example: competency $(0,407)$, management $(0,351)$, productivity $(0,093)$, development activity $(0,092)$, and quantity $(0,056)$. Factors which influence tool and machine in brem production system, in example : amount $(0,571)$, volume $(0,3)$, and sophistication level $(0,129)$. Factors that effected method in brem production system, in example: standard operating procedure $(0,298)$, time efficiency $(0,282)$, process type $(0,274)$, and quality control $(0,147)$. Benchmarks for goals to be achieved by the production system is the effectiveness of brem Madiun $(0,548)$, productivity $(0,227)$, efficiency $(0,138)$, and quality $(0,087)$.

2. Strategies Development Policy

Strategies that can be done on developing the brem industry in Madiun are provision of venture capital to support the administrations, improvement of licensing services, improvement of joint venture accessibility on infrastructure production, supporting on marketing, improvement of human resources quality (coaching and training), development of product, improvement of business management, and development on network of business partnership respectively. 


\section{REFERENCES}

[1] Pujawan, N. 2004. Upaya Peningkatan Kualitas Brem Madiun Dengan Penambahan Natrium Bikarbonat. Jurnal Boga Dan Gizi 3 (1) : 5-9.

[2] Harijono. 2001. Pengaruh Penambahan Sorgum dan Kepekatan Adonan Terhadap Kualitas Brem Padat. Jurnal Makanan Tradisional Indonesia, 1 (1) : 12 - 15.

[3] Ariyanto, G. 2003. Brem Khas Tapi Berkendala. Kompas Edisi Selasa 18 Maret 2003.

[4] Pugeruni, 2003. Pembuatan Brem Ketan Hitam (Kajian Penambahan Air Tape Ketan Putih dan Penambahan Bahan Pengembang Terhadap Sifat Fisik, Kimia dan Organoleptik). Skripsi. Universitas Brawijaya. Malang.

[5] Anonymous. 2006. Profil Industri Kecil dan Kerajinan Rumah Tangga: Tahun 2004. BPS. Jakarta.

[6] Suhardi, D. 2009. Pengembangan Proses dan Peralatan Pembuatan Kue dan Minuman Brem dari Buah - Buahan Tropis. Balai Penelitian dan Pengembangan Industri. Surabaya.

[7] Ariani, M. 2007. Penguatan Ketahanan Pangan Daerah Untuk Mendukung Ketahanan Pangan Nasional. Pusat Penelitian dan Pengembangan Sosial Ekonomi Pertanian. Bogor.

[8] Anonymous. 2005. Peran Usaha Mikro, Kecil, dan Menengah Dalam Pembangunan Ekonomi Nasional. Rapat Kerja Nasional I GARANSI, Kementrian Negara Koperasi dan Usaha Kecil dan Menengah. Surabaya.

[9] Anonymous. 2011. Sentra Andalan yang Seperti Disiakan. Buletin Litbang Dwi Bulanan TEROPONG, Edisi 55. Surabaya.

[10] Assauri, A. 2004. Manajemen Produksi Perencanaan Sistem Produksi. BPFE. Yogyakarta.

[11] Djauhari, L. 2003. Manajemen Strategi dan Kebijakan Perusahaan. Erlangga. Surabaya.

[12] Setiadi, E. 2009. Pembuatan Technology Berdasarkan Penilaian Dengan Menggunakan Pendekatan Teknometrik. Tesis. Program Pasca Sarjana Magister Teknik Industri. Universitas Indonesia. Jakarta.

[13] Guerrero, U. 2009. Perancangan dan Pengembangan Produk. Salemba Teknika. Jakarta.

[14] Aditya, H. 2004. Analisis Pengaruh Merk, Orientasi Strategik, dan Inovasi terhadap
Keunggulan Bersaing (Studi pada UKM Tanggulangin di Kota Sidoarjo). Jurnal Sains Pemasaran Indonesia, Vol. III, No.3.

[15] Glendoh, S., 2001. Pembinaan dan Pengembangan Usaha Kecil. Jurnal Manajemen dan Kewirausahaan Vol 3. No. 1.

[16] Karsidi, R. 2005. Pemberdayaan Masyarakat Untuk Usaha Kecil dan Mikro (Pengalaman Empiris di Wilayah Surakarta, Jawa Tengah). Seminar Nasional "Pengembangan Sumberdaya Manusia Indonesia". Program Studi Ilmu Penyuluhan Pembangunan Sekolah Pascasarjana. IPB. Bogor.

[17] Handoko, T. 2002. Dasar - Dasar Manajemen Produksi dan Operasi. BPFE. Yogyakarta.

[18] Sudarmo, I. 2007. Sistem Perencanaan dan Pengendalian Produksi, Edisi Kedua. BPFE. Yogyakarta.

[19] Budi, A. 2009. Manajemen Purchasing, StrategiPengadaan dan Pengelolaan Material untuk Perusahaan Manufakturing. PT Elex Media Komputindo. Jakarta.

[20] Stevenson, K. $2007 . \quad$ Operations Management Strategy and Analysis. Addison - Wesley Publishing Company, Inc. USA.

[21] Brown, A. 1994. Strategic Selling in Management. Research Paper Series : Seri Penelitian Manajemen No.03.

[22] Anonymous. 2012. Daftar UMK (Upah Minimum Kabupaten/Kota) di Jawa Timur. Disperindag Jawa Timur. Surabaya.

[23] Zanaria, A. 2007. Sikap Manusia, Teori, dan Pengukurannya. Pustaka Pelajar. Yogyakarta.

[24] Prijono. 2002. Memperkecil Beban Ketergantungan Penduduk Anak dan Remaja, Usia Lanjut serta Rentan Terhadap Usia Produktif. Makalah BKKBN 1 (1) : 12 15.

[25] Syahlan, K. 2004. Kewirausahaan Manajemen Usaha Kecil. Salemba Empat. Jakarta.

[26] Herjanto, E. 2006. Manajemen Operasi. Edisi Ketiga. PT. Gramedia Widiasarana Indonesia. Jakarta.

[27] Riyanto, B. 2001. Dasar - Dasar Pembelanjaan Perusahaan, Edisi Keempat, Cetakan Ketiga. BPFE. Yogyakarta.

[28] Ahyari, A. 2002. Manajemen Produksi dan Pengendalian Produksi. BPFE. Yogyakarta.

[29] Suladra, G. 2004. Strategi Pengembangan Industri Brem dalam Pemberdayaan 
Ekonomi Masyarakat di Desa Gebang Kecamatan Nguntoronadi Kabupaten Wonogiri. UNS Press. Surakarta.

[30] Sedarmayanti, D. 2001. Penciptaan Sistem Penilaian Kinerja yang Efektif dengan Assesment Centre. Jurnal Manajemen Vol. 6, No. 1. Yogyakarta.

[31] Nasution, M. 2001. Manajemen Mutu Terpadu (Total Quality Management). Ghalia Indonesia. Jakarta.

[32] Kuncoro, M. 2003. Metode Riset untuk Bisnis dan Ekonomi. Penerbit Erlangga. Jakarta.

[33] Rahardjo, S. 2009. Sinergi Penerapan UU Nomor 20 Tahun 2008 Terhadap Perbaikan Iklim Usaha dan Pemberdayaan UMKM. Infokop Vol : 17, No : 7.

[34] Arsyad, S. 2006. Identifikasi Faktor-Faktor yang Mempengaruhi Kinerja UKM Catering di Kota Bandung. Jurnal Manajemen Teknologi Vol. 10, No. 2 : 162 - 184. 